\title{
Chapter 6 \\ Brazilian Ethnoracial Classification \\ and Affirmative Action Policies: Where Are \\ We and Where Do We Go?
}

\author{
José Luis Petruccelli
}

\subsection{Introduction}

The present chapter was inspired by an article (Prewitt 2005), which aimed to examine the future of the racial classification in the censuses of the USA. With the longest statistics tradition in that matter - more than two centuries of ethnic and racial categorisation of its population - the USA dared to implement a radical change in the census of 2000 , allowing respondents to identify officially with as many racial groups as they saw fit (Williams 2006). Although only a few countries in the Americas include in their statistical surveys the ethnic origin of its inhabitants (Allan 2001), there is wide consensus about ethnicity, race, colour or origin as a key variable for understanding current societies. Its measurement became an indispensable resource for the detection of racial inequalities and, consequently, for the creation of compensatory policies.

There is a reasonable statistical tradition of racial classification in Brazil, although it has only been continuously incorporated in household surveys since the 1980s. The first national census of 1872 enumerated the population and classified it racially according to categories that a hierarchically organized Brazilian society used for the ethnoracial identification of its members. This same basic procedure was applied in the last demographic census, carried out in 2010. However, up to now, throughout these 135 years, political, techno-scientific and demographic considerations added or subtracted certain racial categories of the classification, or in some cases, eliminated the racial classification itself. Consequently, certain periods suffered from a lamentable lack of information, as occurred in the half century between 1890 and 1940. However, the 'hard core' of the racial categorization, consisting, on one hand, of the black/white dichotomy, and on the other, the residual

\footnotetext{
J.L. Petruccelli $(\bowtie)$

Brazilian Institute of Geography and Statistics (IBGE), Rio de Janeiro, Brazil

e-mail: jlpetru@uol.com.br
} 
classifications of mixed groups and native peoples, remained untouched during that long period of Brazilian social history. This continuity persisted in spite of the enormous differences between the second half of the nineteenth century, the time of the first census, and the beginning of the twentieth century. To mention the most conspicuous example, in 1872 slavery was still effective during the imperial period. In current times, after the 2001 Durban conference where even the Brazilian government recognized the existence of racism in the country and engaged to combat it, the battle for the acceptance of multiculturalism and the introduction of affirmative action policies characterize a period of social transformations concerning the construction and recognition of new identities.

Such different social realities point to a probable inadequacy of the current Brazilian system persistently in place, and makes the following question unavoidable: where are we and where are we going to in terms of ethnoracial classification in the country?

\subsection{The Racial Classification}

As in the USA, the public face of Brazilian racial classification is its population census, thus the racial categories used on the census are socially perceived as 'official'. However, an aspect of this classification, included in the first national statistical operation, reflected the legal status of part of the inhabitants of the country: their civil condition of servitude. Differentiated from the inhabitants of free condition, the captives were classified mainly as black in the census, or, less frequently, as brown. On the other hand, by that time the country counted with a large contingent of free African-descent population, classified mainly as brown. Because of this, black became strongly associated with enslavement, while brown became associated with free descendants of former slaves. 'It was from the separation between free and enslaved that the profile of this society defined clearer its contours and projected it in the 1872 census' (Oliveira 2003).

Beyond the rigidity of the racial classification system mentioned above, a constant has been verified since 1872 until the present date: the discomfort generated by the uncertainty of the mixed groups. This resulted in a 'residual' category, which usually came under the label of brown, although the 1890 census used the term 'mestizo'. In the particular case of the 1940 census, the instructions for enumerators were to draw a dash in the corresponding place of the form for any of those answers that were outside the black-white basic dichotomy, these were later tabulated as brown. This occurrence is one of the few alterations carried out so far, in a period in which 11 national level censuses of population have been completed, in 3 of which, 1900, 1920 and 1970, the racial classification was omitted. The 1950 census added the category of brown to the other three currently used: white, black and yellow. From 1980 to 2000, the racial classification appears exclusively in the long form of the census, applied only to a sample of the population. Nevertheless, the 2010 census returned it to the general or basic form, which concerns the whole population. 
One other modification took place with the caboclo term, used in the 1872 and the 1890 censuses for the native nations. The absence of this category in the 1940 , 1950, 1960 and 1980 censuses, forced to include these groups in the brown category. In this way, Brazilian Indians were ignored for a whole century in the national statistics, although they constituted $9 \%$ of the total population in 1890 . They only reappeared statistically in 1991 with the indigenous category. In this same year, the classification changed from 'colour' to 'colour or race', apparently because it counted the native peoples separately. The categories of 'colour', such as white, brown, black or yellow, were now differentiated from what would constitute a classification of 'race', such as Indian. The myth of Brazilian national origin was thus statistically completed in 1991 as expression of 'the intercrossing between the Portuguese colonists, the African slaves and the native population' (Oliveira 2003). The 2000 and 2010 censuses, despite numerous complaints and critiques, kept the classification identical, as well as other surveys conducted in this decade.

\subsection{Studies on Racial Inequalities}

Since the end of the 1970s, several studies on racial inequalities were carried out, based on the first household survey to include open racial classification in 1976. They have shown that, despite the perceived gradation socially expressed in the three categories of white, brown and black, the Brazilian system of social discrimination behaves in a bipolar way: the whites located in a much more favourable position than Afro-descendants. Therefore, the dichotomy whites/non-whites - the latter identified as black and brown - characterize the paradigm of the contrast between those who have and those who do not have racial advantages, with doubtless effect in the interpretation of the data on racial inequalities. Social justice policies formulated in response to statistical findings are accepted world-wide, being that 'the ideal of equal opportunity fuelled a demand for more equal outcomes, and as the negative goal of nondiscrimination turned into the proactive policy of redress that came to be called affirmative action' (Prewitt 2005). Therefore, statistical disparity worked its way into the implementation of policies and definition of laws to fight the exclusion and to promote social mobility of specific groups.

The historical generator of the concept and the practice of positive discrimination policies is B.R. Ambedkar (1891-1956), Dravidian thinker and militant. Jurist and historian, he argued that in the case of twentieth-century India, it would be impossible to dismantle the caste system without the adoption of focused specific measures, concerning the 'untouchable' and 'stigmatized tribes' who represented $65 \%$ of the population. Contrary to conventional wisdom, which holds that compensatory policies originated in the USA (and later emulated in Brazil), Ambedkar already considered in 1928 (Shet 1998) for the first time the proportional representation of the depressed classes in the national elections (separate electorate), and his demand configured the founding idea of the public policies of affirmative action. Furthermore, as prime minister of Justice of independent India, he included affirmative action policies in the first constitution of the country of 1949 (Gautam 2000). 
During the 1940s and 1950s, and as a consequence of the decolonization process in African and Asian countries, similar policies of preferential treatment for ethnic minorities were proposed and implemented in Pakistan, Indonesia, Malaysia, Ghana and Guinea, amongst others. They followed the pioneering trajectory of India, which reflected in the USA initiatives, better known in Brazil. By the 1990s demographic changes, the end of apartheid in South Africa and the rise of multiculturalism transformed the political panorama. New political demands questioned the existing racial and ethnic categories in Brazil, together with the need for better identification of the groups to be targeted with compensatory policies for their now officially recognized disadvantages.

The question of racial classification raises diverse arguments, from orthodox Marxism up to ideological right-wing positions, trying to depict the difficulties of identifying who the beneficiaries of the proposed actions would be. The ghost of the miscegenation ideology rises again to contest the justice of the compensatory policies. If Brazilians are all mixed, runs the argument, they would be all 'equal' and it could not be a means of differentiating blacks from non-blacks, since all would have something to do with African origins. To this 'ideological' position a 'scientific' point of view recently emerged: the geneticists discourse about the genealogical mixture of the ancestries of Brazilian whites, shuffling genomic characteristics with social representation of ethnoracial identity, in spite of the well-known differences between origin (and DNA) and colour (or mark). Yet, whatever the extent of racial mixture in the country 'the majority have lacked the basic rights associated with citizenship for most of the twentieth century and for all of the country's earlier history' (Nobles 2000).

The fact is that the discourse of black identity and the real possibility of achieving racial equality are thus delegitimized: in this way, the affirmation of the unequal condition of blacks in Brazil is silenced. 'Because the discourse of blackness would dislocate the debate from an abstract celebration of the interpenetration of cultures to a vehement denunciation of the precarious and always unequal life conditions faced by the black population in the country of the supposed racial democracy' (Carvalho 2005). Thus, the vindication of racial mixture is presented as the solution for ethnic conflict and racial prejudices, allowing 'the reproduction of a simulated modality of racism (the so called $<$ Brazilian racism $>$ that intends to be adapted to the self-representation of Brazilians as “cordial man”)' (Oliveira 1997).

\subsection{What Surveys Say}

The results of two national surveys: the $1976 \mathrm{PNAD}^{1}$ and the $1998 \mathrm{PME}^{2}$ counterbalance the arguments of uncertainty concerning racial categorization in Brazilian society. Both surveys included two questions on colour or race and two on origin,

\footnotetext{
${ }^{1}$ National household survey.

${ }^{2}$ Monthly employment survey.
} 
an open-ended one, of spontaneous response, and a pre-codified one. The results obtained promoted the notorious debate on how many categories of colour occur in the country. Both surveys found, in terms of number of answers, more than a hundred different terms. This initially perceived multiplicity of categories supported the idea of the supposedly enormous complexity of the Brazilian classification system. Ideologically pushing a bit further, the conclusion was that it is not possible to know who black is and who is not. However, among such terminological variety, just a few terms appear as statistically significant. Thus, of the 143 terms found in the PME-98, 77, more than half of them, appear only once in the sample and 12 other identifications are related to nationality or state of origin or birth. Furthermore, variations of basic categories found may compose single groups and, finally, 16 categories complement or modify 'white' with some particular name or adjective, seeming to relate to a hierarchic differentiation with the 'pure' white. Therefore, a small set of denominations of spontaneous use cover almost the entire range of identifications collected, just 7 categories - including white, brown, black, Moreno and yellow - incorporate $97 \%$ of the answers and only 10 categories cover $99 \%$ of them (Petruccelli 2004). However, this is commonly omitted in the studies and papers that dogmatically indicate supposed insurmountable difficulties concerning the Brazilian ethnoracial identification, such as the exaggerated heading of a newspaper's article 'The 300 colours of Brazilians'. In consequence, it deserves to be outlined that almost all Brazilians identify themselves according to a well-restricted set of colour categories.

\subsubsection{Polysemy and Ambiguity of the Brown Category}

Nevertheless, an important ambiguity persists - in the intention to improve the system of racial classification as in the elaboration of affirmative action policies - concerning the pertinence of the brown category at the national level and particularly in the Centre-West and North regions of the country. 'What it is classified in each region as brown has a historical origin and a distinct and absolutely singular ethnic reality' (Oliveira 1997). As was already pointed out, the term designates in fact a residual category in the system of colour classification, within which can be distinguished at least three types of ethnic groups: firstly, the group that identifies itself in this way for its phenotype perceived as from African ancestry, which is, without any doubt, the majority of this category. Secondly, a group that can be identified as predominantly Indian-descendant, characteristic of the regions mentioned above, that identifies himself with the brown colour and that refers historically to the caboclo figure. Finally, a population group found basically in the Federal District, but also in other cities and that, as Carvalho (2005) points out, represents 'a way to express an adhesion to a specific historic-geographic condition' and not an identification of colour in the sense of physical appearance, since they are, in the practice of social relations, perceived as whites. 
The studies on racial inequalities and discrimination at the national level are fully justified placing together black and brown categories into a single category, because of their enormous similitude of behaviour and the significant separateness with the white group. Nonetheless, it is also methodologically relevant to try the possibility of better identifying and differentiating socio-racial categories, such as the mentioned above, that present secular persistence and sociological consistency in specific regions. In consequence, instruments and information should be improved in order to fit better to the social reality, in the understanding that the ethnoracial identification aims to allow the free expression of identities as well as to promote the correct formulation of laws and anti-discriminatory measures. 'The statistic classification presents a normativity that points out to two contingent registers: that of description and knowledge, related to science, and that of description and action, related to politics' (Simon 2005a). The possibility of joining any categories would be sustained, preserving their double justification: 'Statistically, for the uniformity of socio-economic characteristics of both groups and theoretically, for the fact that discriminations, potentials or effective, suffered by both groups, are of the same nature' (Osorio 2003).

\subsubsection{Racial Classification: Its Relational Nature}

The former reflections led to the following questions: Which would be the proper number of ethnoracial categories? Moreover, what would be the best form to take account of the mentioned specificities, granting the necessary recognition to the expression of socially distinct identities and regional differences? According to Melissa Nobles, currently 'there are no laws, social mores, intellectual agreements or general consensus about what constitutes a racial identity' (quoted by Prewitt 2005). However, Brazilian society demonstrates a forceful racial polarization, suggesting that race is a variable that profoundly structures society. What expresses this reality is the recurrent socio-economic inequalities present in every social research report. The most diverse information converges to show that ethnoracial group membership is a determinant for social exclusion. Among the reasons underlined for this reality figures the 'permanence, along the twentieth century, of diverse discriminatory practices in the repressive apparatus, the judiciary system and other state and civil institutions... against the Afro-descendant population, hindering its physical and social mobility' (Paixão 2003). Discrimination exists as a current practice suffered by people according to appearance or colour, among other characteristics, like those perceived as of aboriginal origin or darker skin. It 'is very frequent, in the world and in Brazil, that the origin of an individual, his physical appearance, his culture and other traces of identification (religion, way to dress, accents and used dialects), is still today, used as a way to establish hierarchical relations between people and collectives' (Paixão 2004). Furthermore, racial categorization - the output of an operation of perception and attribution of a 'score' in a scale of colour classification - works as a contextual phenomenon, meaning that the same person 
can be perceived and classified differently according to context, the group and the region of reference. However, this is not an obstacle to the feasibility of a classification system in surveys, since the ultimate goal is that each person should be identified in agreement with how he/she is perceived and self-identified in his/her context. 'Being the border lines that separate the three most conspicuous zones of colour black, brown and white - fluid, the classification gains the capacity to apprehend the situation of the individual classified in his social microcosm, in the relational context that effectively counts in the definition of pertaining to the discriminating group or the discriminated one' (Osorio 2003).

\subsection{Critical Perspective}

The various studies that coincide in pointing to the relative consistency of the current system of racial classification (Silva 1994; Piza and Rosenberg 1996; Petruccelli 2000; Osorio 2003; Telles 2003), do not deny either the imprecision or the eventual inherent imperfections of this system, mainly concerning the field collection of data. A recurrent issue in many analyses refers to the fact that, despite the explicit instruction of the mandatory of the self-declaration in the colour identification, what actually occurs is a mixture of self with hetero-classification. On the other hand, since a single informer supplies most of the collected information of the household and, as not all the inhabitants are actually present at the interview, this informer usually proceeds to identify the colour of the whole family. Furthermore, 'as there is no information on who answers the questions, it is impossible to distinguish the group of people who had declared his colour to the one that had its colour pointed for another resident of the household' (Osorio 2003). The ideology of the racial relations influences also the context of interview, bringing about difficulties in formulating the question.

\subsection{Conclusions}

It seems to be clear that new approaches concerning the Brazilian classification system, as well as the multiple dimensions implied in the phenomenon of ethnicity, have to contemplate the diverse contemporary expressions of race or colour identity. Although conceptual and methodological reasons may rise before the possibility of changing the measurement of social phenomena, as well as its social and political consequences, 'neither racial measurement nor policy that relies on it is in a settled state - and this provides a historical opportunity for fresh thinking, starting with the term 'race' itself' (Prewitt 2005). Thus, the current debate around racial classification appears as more than pertinent, even urgent. All the representations of identities must have their right of expression guaranteed, a right still to be conquered which means that: 'the fights for ethnic or regional identity, for properties (stigmas or 
emblems) attached to origin through the place of origin and the durable marks that are correlative... are a particular case of the fights for classifications' (Bourdieu 1980).

The persistence of Brazilian structural, institutional and individual racism throughout its 500 years of history has meant that the concept of race (with its correlates, ethnic group and colour) was kept effective as an analytical and political category with its 'nominal existence ... in the social world' (Guimarães 2002) of doubtless symbolic effectiveness in the imposition of the social hierarchy. Thus, racism produces and assumes the concept of race and not the opposite. 'More than an ideology, racism is found in the base of the addition of small decisions, behaviours or appreciations that, chained and repeated in almost invisible routine way, compose a dense system of discriminatory acts and hinder full and entire access for the joy of rights by individuals defined by their ethnic and racial origins' (Simon 2005b). People are the object of discrimination when they are perceived by a culturally shared construction as carrying features that remit to racial categories. Independently of the conscience and attitude of the potentially discriminating agent, the perception of the other as belonging to an ethnic group socially imposes his racial categorization. In addition, when classification is followed by discrimination, the stigmatized groups see themselves through the eyes of the discriminator, thereby reinforcing race. 'To refuse the entrance in public space to agents defined by a particularism including more or less explicitly a concept of race, is to deny this particularism, to intend to reject it or to crush it, when, very frequently, it has been inflicted to the concerned agents by coups of social exclusion or discrimination' (Wieviorka 1994).

The urgent and obligatory recognition of multiculturalism and the multiethnic reality of the country calls for the development of studies and analyses that will improve current knowledge about how ethnoracial categorization is constructed and used; this will doubtless help to develop a better ethnoracial classification system. 'Once collected, racial and ethnic data are the raw materials for a wide range of policies and laws' (Nobles 2000). Even if aiming at a 'non-racial' democracy and the deconstruction of the notion of race, it is imperative to continue looking for the elaboration of an improved racial classification, relevant to the formulation of public policies that aim to promote a still delayed inter-ethnic coexistence, which is, fair, balanced and equitable. Therefore, 'on moral and methodological grounds, the classification used in census 2000 can and should be improved' (Prewitt 2005), in the USA, as expressed by the quoted author and should certainly be improved in Brazil.

Open Access This chapter is distributed under the terms of the Creative Commons Attribution Noncommercial License, which permits any noncommercial use, distribution, and reproduction in any medium, provided the original author(s) and source are credited. 


\section{References}

Allan, J.-A., (2001). Review of the measurement of ethnicity: International concepts and classifcations. Wellington: Statistics New Zealand, $44 \mathrm{p}$.

Bourdieu, P. (1980). L'identité et la représentation: Éléments pour une réflexion critique sur l'idée de région. Actes de la Recherche en Sciences Sociales, 35, 64-72.

Carvalho, J. J. (2005). Inclusão étnica e racial no Brasil: A questão das cotas no ensino superior, 206. São Paulo: Attar.

de Oliveira, J. P. (1997). Pardos, mestiços ou caboclos: Os índios nos censos nacionais no Brasil (1872-1980). Horizontes Antropológicos, 3(6), 60-83.

de Oliveira, J.S. (2003). Brasil mostra tua cara': Imagens da população Brasileira nos censos demográficos de 1872 a 2000 (Texto para Discussão No. 6), 54. Rio de Janeiro: ENCE/IBGE.

Gautam, C. (2000). Life of Babasaheb Ambedkar. London: Ambedkar Memorial Trust. http:// www.ambedkar.org/Babasaheb/lifeofbabasaheb.htm.

Guimarâes, A. S. (2002). Classes, raças e democracia, 231. São Paulo: Editora 34.

Nobles, M. (2000). Shadows of citizenship. Race and the census in modern politics, 248. Palo Alto: Stanford University Press.

Osorio, R. (2003). O sistema classificatório de 'cor ou raça' do IBGE (Texto para discussão No. 996), 50. Brasília: IPEA.

Paixão, M. (2003). Desenvolvimento humano e relações raciais, 159. Rio de Janeiro: LPP-DP\&A.

Paixão, M. (2004, novembro). Conferência Pela promoção da Igualdade Racial: Tese Guia. Rio de Janeiro. http://observatorioafrobrasileiro.org/.

Petruccelli, J.L. (2000), A cor denominada (Texto para Discussão No. 3), 54. Rio de Janeiro: DPE/ IBGE.

Petruccelli, J. L. (2004). Políticas de ação afirmativa e classificações da cor: usos e abusos da estatística, Estudos Afro-Asiáticos, Rio de Janeiro, UCAM, (26):7-25.

Piza, E., \& Rosenberg, F. (1996). “Cor nos Censos Brasileiros”, Revista da USP, dez/fev 98/99.

Prewitt, K. (2005). Racial classification in America: Where do we go from here? Daedalus, 134, 5-17.

Shet, S. (1998). Life \& thoughts of Dr. Bheemrao Ramji Ambedkar 1891-1956, http://www.indianskeptic.org/html/is_v03/3-11-4.htm.

Silva, N.V. (1994). Uma nota sobre "raça social" no Brasil. In Estudos Afro-Asiáticos 26, 97-80. Rio de Janeiro: UCAM.

Simon, P. (2005a). La construction des catégories de l'ethnicité: Le savant pris dans le politique, Groupe de Recherche sur la Socialisation, Séminaire, http://recherche.univ-lyon2.fr/grs/index. php?page $=27 \&$ seance $=18$.

Simon, P. (2005b). Le rôle des statistiques dans la transformation du système de discrimination: La montée des discriminations ethniques ou raciales, Séminaire, http://seminaire.samizdat.net/ article.php3?id_article $=113$.

Telles, E. (2003). Racismo à Brasileira: Uma nova perspectiva sociológica, 347. Rio de Janeiro: Relume Dumará.

Wieviorka, M. (1994). Les paradoxes de l'antiracisme, Esprit, Paris, 205:16-28.

Williams, K. (2006). Mark one or more: Civil rights in multiracial America, 196. Ann Arbor: The University of Michigan Press. 